\title{
Calicivirus ile enfekte kedilerde adenozin deaminaz 1, paraoksonaz 1, C-reaktif protein ve serum amiloid $A$ düzeylerinin araştırılması
}

\author{
Seda Sarkaya ${ }^{1}$, Halil İbrahim Gökce ${ }^{2}$ \\ ${ }^{1}$ Palm Veteriner Kliniŏi, Antalya, TÜRKIYE \\ ${ }^{2}$ Iç Hastalıkları Anabilim Dalı, Veteriner Fakültesi, Burdur Mehmet Akif Ersoy Üniversitesi, Burdur, TÜRKIYY
}

Anahtar Kelimeler:

adenozin deaminaz 1 (ADA-1)

akut faz yanit

calicivirus

kedi

\section{Key Words:}

acute phase response,

adenosine deaminase 1 (ADA-1)

calicivirus

cat

$\begin{array}{ll}\text { Geliş Tarihi } & : 14.07 .2021 \\ \text { Kabul Tarihi } & : 11.10 .2021 \\ \text { Yayın Tarihi } & : 31.12 .2021 \\ \text { Makale Kodu } & : 971635\end{array}$

Sorumlu Yazar:

Hİ GÖKCE

(higokce@mehmetakif.edu.tr)

ORCID

S. SARIKAYA: 0000-0003-2128-6688 HI. GÖKCE : 0000-0002-4458-0671

Bu araștırma Burdur Mehmet Akif Ersoy Üniversitesi Bilimsel Araştırma Projeleri Koordinatörlüğü tarafindan 0577-YL-19 proje numarası ile desteklenmiștir.

\begin{abstract}
ÖZ
$\mathrm{Bu}$ çalıșma ile feline calicivirus (FCV) ile enfekte kedilerde hücresel immün yanıtın, oksidatif stresin ve yangısal sürecin belirlenmesi amaçlanmıştır. Çalışmada FCV ile enfekte 20 adet kedi ve 10 adet klinik olarak sağlıklı olmak üzere toplam 30 kedi kullanılmıştır. Çalışmada tüm kedilerden toplanan serum örneklerinde kedi spesifik ELISA test kitleri kullanılarak adenozin deaminaz 1 (ADA-1), paraoksonaz 1 (PON-1), C-reaktif protein (CRP) ve serum amiloid A (SAA) düzeyleri belirlenmiştir. Sonuç olarak, FCV ile enfekte kedilerin serum ADA-1, SAA ve CRP düzeyleri kontrol grubununkilerden istatistiksel olarak önemli düzeyde yüksek bulunmuştur. Ayrıca enfekte kedilerin PON-1 düzeyleri ise kontrol grubundan önemli düzeyde düşük olduğu belirlenmiştir $(\mathrm{p}<0,001)$. Yapılan bu çalışmada, ADA-1 ile PON-1 arasında yüksek düzeyde anlamlı negatif korelasyon $(\mathrm{r}=-0,73 ; \mathrm{p}<0,001)$ saptanırken diğer parametreler arasında ise orta düzeyde korelasyonlar belirlenmiștir. Sonuç olarak, elde edilen veriler FCV ile enfekte kedilerde ADA-1 düzeyindeki artıș aktive olmuş hücresel yanıtı, PON-1 düzeyindeki düşüş oksidatif stresin geliştiğini göstermektedir. Ayrıca SAA ve CRP düzeylerindeki artışlar ise bu kedilerde akut faz yanıtın geliştiğini ortaya koymaktadır. Bu çalışma, FCV ile enfekte kedilerde ADA-1'in hücresel immün yanıtın durumunun belirlenmesinde, PON-1'in oksidatif stresin belirlenmesinde yararlı biyomarkırlar olabilir. Bunlara ek olarak SAA ve CRP'nin gelişen yangıya bağlı akut faz yanıtın belirlenmesinde kullanılabilir.
\end{abstract}

Investigations of adenosine deaminase 1, paraoxonase 1, C-reactive protein and serum amyloid A levels in cats infected with calicivirus

\section{ABSTRACT}

The aims of this study were determination of cellular immune responses, oxidative stress, and inflammatory responses in cats infected with FCV. In the study, 20 cats infected with FCV and 10 clinically healthy cats were used. In the study, adenosine deaminase 1 (ADA-1), paraoxonase 1 (PON-1), C reactive protein (CRP) and serum amyloid A (SAA) levels were determined in collected serum samples of all the cats, using cat-specific ELISA test kits. In the present study, serum concentrations of ADA-1, SAA and CRP were significantly higher than those of control group $(\mathrm{p}<0,001)$. Wheras PON-1 concentrations were found to be significantly low compared to that of control group. Furthermore, high negative correlations were obtained between ADA-1 and PON-1 ( $r=-0,73 ; \mathrm{p}<0,001)$, while modarete correlations were obtained between other parameters. In this study, elevated serum ADA-1 levels indicate activated cellular immune responses and decreased PON-1 levels indicate oxidative stress. Furthermore, increased SAA and CRP levels determine the development of acute phase responses in cats infected with FCV. In conclusion, ADA1 and PON-1 can be useful biomarkers for detecting activated cellular immune responses and oxidative stress in cats infected with FCV, respectively. Furthermore, SAA and CRP can be used to detect acute phase responses in infected cats with FCV.

\section{GİRIŞ}

Calicivirus yoğun olarak yavru ve genç kedilerde hafif veya orta şiddette üst solunum yolu enfeksiyonlarina neden olmaktadır $(1,2)$. Daha ender olmakla birlikte kedilerde yüksek derecede virulent sistemik feline calicivirus (VS-FCV) suşları ile çok şiddetli ve öldürücü sistemik enfeksiyonlarda gelişebilmektedir. $(3,4)$. Yapılan çalışmalarda kedilerin üst solunum yolu enfeksiyonlarının \%80'i felin calicivirus virus (FCV) ve Feline Herpes Virus-1 (FHV-1) veya ikisi tarafindan oluşturulduğu saptanmıștır. Bununla birlikte ağızda stomatitis, ülser ve gingivitisle seyreden olguların büyük bir çoğunluğunun ise FCV tarafindan oluşturulduğu anlaşılmıştır $(1,5)$. Özellikle im- mün sistemi baskılanmıs, stres altında yaşayan, iyi beslenemeyen, kalabalık ve hijyenik olmayan ortamlarda barındırılan yavru ve genç kediler risk altındadır (2). Hastalığ1 atlatan kediler ya aralıklarla ya da taşıyıcı olarak ömür boyu virus saçmaktadır $(6,7)$. FCV yüksek derecede genetik ve antijenik çeşitliliğe sahip oduğundan virusun çok sayıda biyotipi mevcuttur. Ayrıca FCV yüksek düzeyde ve hızlı mutasyon yeteneğine sahiptir (8). Bu özelliklerinden dolayı kedilerde așılar farklı biyotiplere karşı yeterli korunma sağlayamamaktadır (9).

Adenozin deaminaz-1 (ADA-1) yoğun olarak lenfositlerde ve monositlerden üretilir ve özellikle hücresel immün yanıtın bir göstergesidir. ADA lenfositlerin başkalaşımı, çoğalması ve 
olgunlașması için son derece önemlidir (10-12). ADA yoğun olarak T lenfositlerde bulunduğundan şiddetli hastalık tablolarında ADA-1 artışı T lenfosit aktivasyonunun veya hücresel immün yanıtın bir markırı olarak kabul edilir $(11,13)$. ADA yetersizliğinde ise hem $\mathrm{B}$ hem de $\mathrm{T}$ lenfositlerin sayıları düsser ve fonksiyonları aksar. Bu nedenle ADA yetersizliği immün yetmezlikle sonuçlanır ve buna bağlı organizmada oportunistik fungal, bakteriyel ve viral enfeksiyonlar daha kolay gelişir (13).

Paraoksonase yoğun olarak karaciğerden, daha az oranda da diğer dokulardan sentezlenen bir enzim olup hem antioksidan bir madde hem de bir negatif akut faz proteindir. Oksidatif stresin belirlenmesinde antioksidan olarak ve yanginın belirlenmesinde de negatif akut faz protein olarak kullanılmaktadir (14-18).

C-reaktif protein (CRP) ve serum amyloid A (SAA) pozitif akut faz proteinler (AFP) olup akut faz yanıta (AFY) bir cevap olarak karaciğerden üretilirler. Kandaki konsantrasyonları yang1ya sebeb olan enfeksiyon, travma cerrahi müdahale ve hatta stress durumlarında hizla artar. Bu akut faz proteinleri yanginın tanısinda, şiddetinin belirlenmesinde, bakteriyel ve viral hastalikların ayrımında ve tedavinin takibinde kullanılmaktadır (1921)

Bu güne kadar calicivirus ile enfekte kedilerde hastalığın patogenezini aydınlatacak oksidatif stres parametresi olan PON-1 ve hücresel immün yanıtın durumunu gösteren ADA-1 ile ilgili herhangi bir çalışmaya rastlanmamıştır. Bu çalışmada ise calicivirus ile doğal enfekte kedilerde hem ADA-1 hem de PON-1 ölçülerek bu enzimlerin diagnostik önemi ortaya konulmuş ve bunların hastalığın patogenezindeki rolü araştırılmıştır. Ayrıca çalışmada doğal enfekte kedilerde CRP ve SAA gibi akut faz proteinleri de belirlenerek akut faz yanıtın durumu ve bunların diagnostik önemleri değerlendirilmiştir.

\section{GEREÇ ve YÖNTEM}

\section{Hayvan Materyali}

Burdur Mehmet Akif Ersoy Üniversitesi Veteriner Fakültesi İç Hastalıkları Küçük Hayvan Kliniği’ne ve Antalya merkezde bulunan serbest veteriner kliniklerine getirilen sahipli kediler sahiplerinden onam formu imzalatılarak çalışmaya dahil edilmiştir. Klinik olarak calicivirus enfeksiyon şüphesi gösteren ve ateş, hapşırık, burun ve göz akıntısı, konjunktivitis, oral stomatitis ve ülserler, kronik gingivitis, dilde ülserasyon gibi belirtiler gösteren kediler çalışmaya dahil edilmiştir $(1,2,5)$. FCV şüphesi taşıyan kedilerden lezyonun olduğu bölgeye öncelik verilmek şartı ile ağız ve burundan svaplar alındı ve teşhis şansını artırmak için bu sıvaplar birleştirildi $(2,22)$. Bu örnekler prosedürlerine uygun olarak kedi spesifik antijen hızl test kitleri ile FCV (Genbody, Chungcheongnam-do, KORE) ve felin herpesvirus-1 (FHV-1) (Asan Pharm. Co. ltd., Seoul, KORE) için test edildi. Testler sonucunda FHV-1 pozitif olanlar çalışmadan ç1karılarak sadece FCV yönünden pozitif olan 20 kedi çalışmaya dahil edildi. Ayrıca 10 adet klinik olarak sağlıklı ve testlerde FCV ve FHV-1 yönünden negatif olan kediler çalışmaya kontrol grubu olarak eklendi. 21 gün içinde FCV ile aşılanmış ve 8 haftalıktan küçük kediler yanlış pozitifliğe neden olacağı için çalışmaya dahil edilmemiştir $(6,22)$.

\section{Laboratuvar Analizleri}

Belirtilen klinik belirtilere sahip FCV ile enfekte şüphesi olan ve sağlıklı kedilerin kan örnekleri klinikte jelli pıhtı aktivatörlü tüplere alınarak elde edilen serum örnekleri PON-1, ADA-1, CRP ve SAA ölçümleri yapılıncaya kadar $-80^{\circ} \mathrm{C}$ 'de saklandı.

Serum örneklerinde CRP (SunRed Shangai, ÇIN), PON-1 (SunRed, Shangai, CIN), ADA-1 (SunRed, Shangai, CIN) ve SAA (SunRed, Shangai, CIN) düzeyleri kedi spesifik ELISA test kitleri ile üretici firmanın önerdiği prosedüre uygun olarak ölçüldü. Oluşan optik dansiteler (OD) ELISA mikroplaka okuyucu ile 450nm dalga boyunda okundu (MR-96A, Minray, China). Her bir parametre için standart stok solüsyonları her defasında 2 katı olacak şekilde 1/256 sulandırma katsayısına kadar sulandirılarak OD değerleri ELISA okuyucuda okundu. Elde edilen OD değerleri ile regresyon analizi yapılarak standart eğri grafiği oluşturuldu ve buradan elde edilen formüllerle her bir parametrenin serum konsantrasyonları hesapland1. Testlerin duyarlılığ1 testin prosedüründe sırası ile ADA-1, PON-1, SAA ve CRP için 0.075ng/ml, 1,682ng/ml, 2,174ng/ $\mathrm{ml}$ ve $0.12 \mathrm{mg} / \mathrm{L}$ olarak verilmiştir.

\section{Istatistiksel Analiz.}

Kolmogorov Smirnov testi verilerin normal dağ1lım gösterip göstermediğinin belirlenmesinde kullanıldı ve normal dağ1lım gösterdiği saptanan parametrelerden calicivirus ile enfekte kedilere ait parametreler ile kontrol grubuna ait parametreler arasındaki istatistiksel faklılıklar bağımsız t test ile analiz edildi. Ayrica calicivirus ile enfekte kedilerden elde edilen veriler arasindaki korelasyon Pearson's correlation coefficient (r) analizi ile belirlendi. Çalışmada bütün parametreler ortalama ve standart sapma (Ort \pm SD) olarak verildi. İstatistiksel analizlerde anlam derecesi $\mathrm{p}<0,05$ olarak kabul edildi. İstatistiksel analizlerin gerçekleştirilmesinde SPSS 21.0 for Windows ${ }^{\circledR}$ paket programi kullanild1.
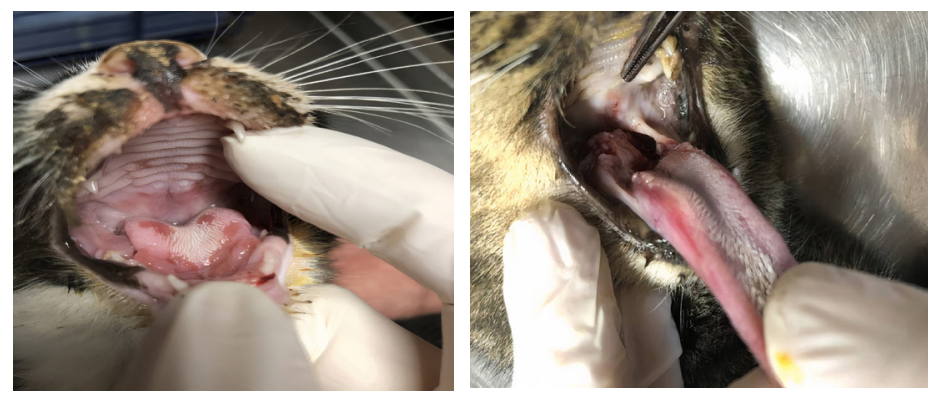

Şekil 1. Calicivirus pozitif Şekil 2. Calicivirus pozitif bir bir kedide dilde ve farenkste kedide dilde ve farenkste ülseratif ülseratif lezyonlar.

Figure 1. Ulcerative tongue lesions of a calicivirus-positive cat lezyonlar.

Figure 2. Ulcerative lesions of the tongue and pharynx in calicivirus-positive cat.

\section{BULGULAR}

\section{Klinik Bulgular}

FCV pozitif olan kedilerde durgunluk, iştahsızlık, göz ve burun akıntısı, oral gingivitis ve stomatitis ile birlikte ağ1z mukozası ve özellikle dilde yaygı̈n ülseratif lezyonlar belirlenmiştir 
(Şekil 1, Şekil 2).

\section{Biyobelirteçlerin Analiz Sonuclar}

Calicivirus ile enfekte kedilerin serum ADA-1 $(p<0,001)$, SAA $(p<0,001)$ ve CRP $(p<0,001)$ düzeylerinin kontrol grubunda bulunan kedilerden istatistiksel olarak anlamlı düzeyde yüksek olduğu belirlenmiștir. Buna karșın calicivirus ile enfekte kedilerin serum PON-1 $(\mathrm{p}<0,001)$ düzeylerinin ise sağlıklı kedilere göre anlamlı düzeyde düşük olduğu saptanmıştır (Tablo 1). Yapilan Pearson korrelasyon analizlerinde ADA-1 ile SAA $(\mathrm{r}=0,60, \mathrm{p}<0,01)$ arasinda, ADA-1 ile CRP $(\mathrm{r}=0,57, \mathrm{p}<0,05)$ arasinda ve SAA ile CRP arasinda $(\mathrm{r}=0,57, \mathrm{p}<0,05)$ orta düzeyde anlamlı pozitif korrelasyonlar belirlenmiştir. Ayrıca PON-1 ile ADA-1 ( $\mathrm{r}=-0,73, \mathrm{p}<0,001)$ arasinda yüksek düzeyde anlam11 negatif korrelasyon saptanırken, PON-1 ile SAA ( $\mathrm{r}=-0,52$, $\mathrm{p}<0,05)$ ve $C R P(r=-0,50, \mathrm{p}<0,05)$ arasinda ise orta düzeyde negatif korrelasyonlar belirlenmiştir (Tablo 2). maktadır (9). Enfeksiyonu atlatan ve hatta klinik olarak sağlıklı görünen kedilerin birçoğu taşıyıcı olmakta ve kalabalık halde tutulan kediler arasında enfeksiyonun yayılmasında büyük rol oynamaktadır. (6,7). Calicivirus enfeksiyonları herpesvirus enfeksiyonları ile birlikte özellikle çok sayıda kedinin bir arada tutulduğu barınak, yetiştirme alanları ve petshoplarda önemli bir problem olarak hala önemini korumaktadır $(6,7)$.

Adenozin deaminaz yoğun olarak lenfositlerde bulunmakta olup immünolojik sistemin olgunlaşması ve özellikle lenfositlerin çoğalma ve değişimlerinde rol oynayan önemli bir enzimdir $(10,11)$. ADA yoğun olarak T lenfositlerde bulunduğundan şiddetli hastalık tablolarında ADA-1 artışı T lenfosit aktivasyonunun veya hücresel immün yanıtın bir markı11 olarak kabul edilir $(12,23,24)$. ADA yetersizliğinde ise hem $\mathrm{B}$ hem de T lenfositlerin sayıları düşer ve fonksiyonları aksar.

Tablo 1. Serum adenozin deaminaz-1 (ADA-1), paraoksonaz-1 (PON-1), C reaktif protein (CRP) ve serum Amiloid A (SAA) değerleri (Ortalama \pm Standart sapma).

Table 1. Serum concentrations of adenosin deaminase-1 (ADA-1), paraoxonase-1, C reactive protein (CRP) and serum amyloid A (SAA).

\begin{tabular}{ccccc}
\hline Parametre & Kontrol $(\mathbf{n}=\mathbf{1 0})$ & $\begin{array}{c}\text { Enfekte } \\
(\mathbf{n = 2 0 )}\end{array}$ & $\begin{array}{c}\text { En düşük-En yüksek } \\
\text { (Enfekte) }\end{array}$ & p değeri \\
\hline ADA-1 $(\mathrm{ng} / \mathrm{ml})$ & $2,50 \pm 0,04$ & $3,62 \pm 0,15$ & $3,34-3,93$ & \\
PON-1 $(\mathrm{ng} / \mathrm{ml})$ & $6,72 \pm 1,65$ & $3,54 \pm 0,84$ & $2,04-5,42$ & 0,001 \\
$\mathrm{SAA}(\mathrm{ng} / \mathrm{ml})$ & $9,71 \pm 3,14$ & $17,23 \pm 4,55$ & $10,78-29,1$ & 0,001 \\
CRP $\mathrm{mg} / \mathrm{L}$ & $2,97 \pm 0,49$ & $4,41 \pm 0,63$ & $3,78-5,94$ & 0,001 \\
\hline
\end{tabular}

ADA-1: Adenozin deaminaz 1; PON-1: Paraoksonaz; SAA: Serum Amiloid A; CRP: C reaktif protein.

Tablo 2. Calicivirus ile enfekte kedilerden $(n=20)$ elde edilen parametreler arasındaki korelasyon $(r)$ değerleri.

Table 2. Correlations ( $\mathrm{r}$ ) between the parameters of cats infected with calicivirus.

\begin{tabular}{ccccc}
\hline Parameters & ADA-1 & PON-1 & SAA & CRP (mg/L) \\
\hline ADA-1 $(\mathrm{ng} / \mathrm{ml})$ & 1 & $-0,73^{* * *}$ & $0,6^{* *}$ & $0,57^{*}$ \\
PON-1 $(\mathrm{ng} / \mathrm{ml})$ & & 1 & $-0,52^{*}$ & $-0,50^{*}$ \\
SAA $(\mathrm{ng} / \mathrm{ml})$ & & & 1 & $0,57^{*}$ \\
\hline
\end{tabular}

ADA-1: Adenozin deaminaz 1, PON-1: Paraoksonaz, SAA; Serum amyloid A, CRP: C reaktif protein, Parametreler arasındaki korelasyonun anlam derecesi sembollerle belirtilmiştir.

$*: \mathrm{p}<0,05, * *: \mathrm{p}<0,01, * * *: \mathrm{p}<0,001$

\section{TARTIŞMA}

Kedilerde genellikle üst solunum yolu enfeksiyonlarına neden olan FCV daha çok kalabalık halde barındırılan genç ve yavru kedileri etkilemektedir $(1,2)$. Bununla birlikte daha ender görülen ancak çok daha öldürücü seyreden sistemik FCV enfeksiyonlarıda belirlenmiştir $(3,4)$. Kedilerde bu virusun çok sayıda biyotipi mevcut olduğundan kedilerde bir veya birden fazla farklı biyotipler tarafindan enfeksiyon oluşturulabilmektedir $(4,8)$. Üretilen aşların birkaç suşu içermesi ve suşlar arasında korunmanın yeterli olmaması nedeniyle aşılamalar yetersiz kal-
$\mathrm{Bu}$ nedenle ADA yetersizliği immün yetmezlikle sonuçlanır ve buna bağlı organizmada oportunistik fungal, bakteriyel ve viral enfeksiyonlar daha kolay gelişir $(11,13)$. Kanda seviyesinin yükselmesi hücresel immünitenin aktive olduğuna azalması ise immün yetmezliğe bir işaret olarak kabul edilmektedir (1013). Yapılan çalışmalarda birçok hastalıkta ADA-1 seviyesinin yükseldiği ve bunun diagnostik önemi olduğu rapor edilmiştir. Bu çalışmalarda ADA-1 seviyesindeki artışı hem insanlarda hem de hayvanlarda T-lenfosit aktivasyonunu ve yangiyı gösteren önemli bir markır olduğu ortaya konulmuştur (23,25-27). 
Tüberkülozlu insanlarda yapılan çalışmalarda ADA-1 seviyesi oldukça yüksek bulunmuş ve ADA-1 tüberkülozun teşhisinde önemli bir markır olarak önerilmiştir (24). Yapılan başka bir çalışmada ise serum ADA-1 seviyesi ile karaciğerde hücresel y1kımlanma arasında pozitif bir korelasyon belirlenmiş ve ADA1 'in karaciğer hasarının belirlenmesinde yararlı bir markır olduğu ileri sürülmüştür (25). Kedilerde yapılan çalışmalarda serum ADA seviyesinin FIV enfeksiyonunda ve feline infeksiyöz peritonitiste (FIP) önemli düzeyde arttı̆̆1 ortaya konulmuştur. $\mathrm{Bu}$ artışlar T-lenfosit veya hücresel immünite aktivasyonuna ve gelişen yangıya bağlanmıştır (26). Ayrıca yapılan çalışmalarda serum ADA-1 ile CRP düzeyleri arasında anlamlı korelasyonlar belirlenmiştir $(28,29)$. Yapılan mevcut bu çalışmada FCV ile enfekte ve ağızlarında ve özellikle dillerinde lezyon bulunan kedilerde serum ADA-1 düzeyleri sağlıklı kedilerinkine göre istatistiksel olarak anlamlı düzeyde yüksek olduğu belirlenmiştir $(p<0,001)$. Bu yükseliş yapılan birçok çalışmada ortaya konulduğu gibi FCV ile enfekte kedilerde yangisal sürecin geliştiğini ve T-lenfosit spesifik hücresel immün yanıtın aktive olduğunu göstermektedir (10,12,13,25-27). Ayrıca yapılan bu çalıșmada FCV ile enfekte kedilerin serum ADA-1 seviyeleri ile SAA $(\mathrm{r}=0,6 ; \mathrm{p}<0,01)$ ve CRP $(\mathrm{r}=0,57 ; \mathrm{p}<0,05)$ arasinda orta düzeyde pozitif korelasyon PON-1 $(\mathrm{r}=-0,73 ; \mathrm{p}<0,001)$ ile ise yüksek düzeyde anlamlı negatif korelasyonlar belirlenmiștir. Belirlenen korelasyonlar dikkate alındığında özellikle ADA-1 ile PON-1 arasında belirlenen yüksek düzeyde anlamlı negatif korelasyonun bu parametrelerin FCV ile enfekte kedilerde gelişen yangının ve aktive hücresel immünitenin belirlenmesinde yararlı olacağı ortaya çıkmaktadır.

Paraoksonaz multifonksiyonel bir enzim olup oksidatif y1kımlanma ve lipid peroksidasyonuna karşı koruyucu, reaktif moleküllerin detoksifikasyonu, ilaçların biyoaktivasyonu, stresin modülasyonu ve hücrelerin çoğalması ve apoptozisinin regüle edilmesinde rol oynar. PON-1 enzim aktivitesi oksidatif stres şartları tarafından regüle edilir. PON-1'in aynı zamanda high dansity lipoprotein (HDL)'nin antioksidatif ve antiinflamatorik özelliklerini regüle ettiği belirtilmektedir $(14,16,18)$. PON-1'in en önemli özelliği antioksidan bir enzim olması ve lipid peroksitleri ve hidrojen peroksitleri hidrolize ederek HDL ve low dansity lipoprotein (LDL)'yi oksidasyondan korumasıdır $(14,16)$. Yapılan çalışmalar PON-1'in sadece antioksidan olmadığ1 aynı zamanda antienflamatuar etkiye sahip olduğu ve karaciğerden sentezlenen önemli bir negatif akut faz protein olduğunu da ortaya koymuştur $(14,30,31)$. Yapılan çalışmalarda birçok hastalıkta Serum PON-1 seviyesinin yang1 ve oksidatif strese bağlı olarak düştüğü ortaya konulmuştur (17,30-32). Feline infectious peritonitis (FIP)'li kedilerde yapılan çalışmalarda enfekte kedilerde PON-1 düzeyinin sağliklı kedilerden anlamlı düzeyde düşük olduğu saptanmıştır. Yapılan bu çalışmalarda PON-1'in FIP'li kedilerin FIP'li olmayanların ayrımında bir biyomarkır olarak kullanılabileceği ileri sürülmüş olup PON-1'deki düşüş gelişen oksidatif stres ve akut faz yanıta bağlanmıştır (17). Ayrıca yapılan çalışmalarda PON-1 düzeyi ile CRP arasında anlamlı negatif korelasyonlar belirlenmiş olup PON-1 ve CRP arasındaki korelasyonun sepsisin ve tedavinin takibinde yararlı markırlar olacağ1 ileri sürülmüştür $(30,33)$. Sonuç olarak yapılan çalışmalarda PON-1'in akut faz yanıtın belirlenmesinde negatif APP olarak ve antioksidan olarak oksidatif stresin belirlenmesinde bir diagnostik biyomarkır olarak kullanılabileceği rapor edilmiştir $(14,15,17,31,32)$. Yaptı̆̆ımız bu çalışmamızda elde ettiğimiz veriler FCV ile enfekte kedilerin serum PON-1 düzeylerinin sağlıklı kedilerden istatistiksel olarak anlamlı düzeyde düşük olduğunu ortaya koymuştur $(\mathrm{p}<0,001)$. Ayrıca çalışmada FCV ile enfekte kedilerin serum PON-1 düzeyi ile ADA-1 arasında $(r=-0,73 ; \mathrm{p}<0,001)$ yüksek düzeyde, PON-1 ile SAA ( $\mathrm{r}=-0,52 ; \mathrm{p}<0,05)$ ve CRP ( $\mathrm{r}=-0,5$; $\mathrm{p}<0,05)$ arasında ise orta düzeyde negatif korelasyon belirlenmiştir. Çalışmada FCV ile enfekte kedilerde belirlenen PON-1 düzeyindeki düşüş enfekte kedilerde oksidatif stresin geliştiğini ve ayrıca akut faz yanıta bağlı olarak negatif akut faz protein (APP) olan PON-1 sentezinin düştügünü ortaya koymaktadır. Ayrıca yapılan korrelasyon analizleri özellikle ADA-1 ve PON1 'in FCV ile enfekte kedilerde yang1sal sürecin ve oksidatif stresin belirlenmesinde yararlı biyomarkırlar olabileceğini ortaya koymaktadir.

CRP ve SAA yang1 sirasında gelişen AFY cevap olarak karaciğerden sentezlenen pozitif AFP'lerdendir. Sağlıklı hayvanlarda oldukça düşük düzeyde bulunurken yang1 sırasında kandaki konsantrasyonları hızla yükselmektedir. Ancak akut faz proteinlerin diagnostik önemi hayvan türlerine göre değişmekte olup kediler için CRP orta düzeyde, SAA ise yüksek düzeyde diagnostik öneme sahiptir $(20,21)$. Yapılan çalışmalarda bu akut faz proteinlerin yangıya bağlı olarak birçok hastalıkta yükseldiği ortaya konulmuştur $(19,34)$. Aynı zamanda CRP'nin bakteriyel enfeksiyonların viral enfeksiyonlardan ayrımında da kullanılabildiğini ortaya koymaktadır (19). Ayrıca yapılan çalışmalar CRP'nin sadece yangının akut markırı olmadığ1 aynı zamanda önemli bir yang1 düzenleyici protein olduğunu göstermiştir. Dolayısı ile CRP enfeksiyonlarda konakçı savunma sistemi için kilit rol oynayan bir proteindir (21). Yapılan çalışmalarda hastalık sırasında serum CRP ve SAA artıșı ile hastalığın ciddiyeti ve tedaviye cevabı arasında mükemmel bir korelasyonu olduğu belirlenmiştir (35). Bu nedenle SAA ve CRP yang1sal olayların şiddetinin belirlenmesinde, yangısal hastalıkları yang1sal olmayan hastalıklardan ayırmada, hastalık süreci ve tedavi başarısının izlenmesinde yararlı olduğu rapor edilmiştir $(19,20,34,35)$. Yaptığımız mevcut bu çalışmada FCV ile enfekte kedilerin serum SAA $(p<0,001)$ ve CRP $(p<0,001)$ düzeyleri sağl1klı kedilere göre önemli düzeyde yüksek bulunmuş olup bu yükselişin muhtemel nedeni ise gelişen AFY sonucu artan AFP sentezleri olduğu düşünülmektedir. Ayrıca SAA ile ADA$1(\mathrm{r}=0,6 ; \mathrm{P}<0,01)$ arasinda ve SAA ile CRP $(\mathrm{r}=0,057 ; \mathrm{p}<0,01)$ arasında orta düzeyde anlamlı pozitif korrelasyon belirlenmiş olup bu korelasyon SAA ve CRP'nin yanginin belirlenmesinde yararlı olabileceğini göstermektedir.

\section{SONUÇ}

Sonuç olarak yapılan bu çalışma ile ilk defa FCV ile enfekte kedilerde serum ADA-1, SAA ve CRP düzeylerinin arttığ1 buna karşın PON-1 seviyesinin ise düştüğü ortaya konulmuştur. FCV ile enfekte kedilerde serum ADA-1 düzeylerindeki artıș bu kedilerde hücresel immün yanıtın aktive olduğunu ortaya koymaktadır. FCV ile enfekte kedilerin serum PON-1 düzeylerinin sağlıklı kedilerden daha düşük olması enfekte kedilerde oksidatif stresin geliştiğini göstermektedir. Antioksidan bir enzim olan PON-1 seviyesindeki düşüş enfekte kedilerde antioksidan kapasitenin düştüğünün bir 
işareti olarak yorumlanabilir. Ayrıca FCV ile enfekte kedilerde pozitif akut faz proteinleri olan SAA ve CRP düzeylerinde Önemli artışlar belirlenmiş olup bu artışlar enfekte kedilerde yang1ya bağlı AFY'nin geliştiğini ve karaciğerden AFP'lerin sentezinin uyarıldığını göstermektedir. Çalışmada elde edilen sonuçlar FCV ile enfekte kedilerde yanginın belirlenmesinde ADA-1, SAA ve CRP, hücresel immün yanıtın durumunun belirlenmesinde ADA-1 ve oksidatif stresin belirlenmesinde ise PON-1 ölçümlerinin yararlı olacağ1 ve bu parametrelerin FCV ile enfekte kedilerde faydalı biyomarkırlar olarak kullanılabileceğini göstermektedir.

\section{BEYANNAMELER}

\section{Etik Onay1}

Bu çalışma hayvan sahiplerine onam formu imzalatılarak ve Mehmet Akif Ersoy Üniversitesi, Hayvan Deneyleri Yerel Etik Kurulu izni alınarak yapılmıştır (Etik Kurul no: 2019/498).

\section{Çıkar Çatışması}

Yazarlar, herhangi bir çıkar çatışması beyan etmemektedir.

\section{Yazar Katkıları}

Tüm yazarlar makalenin her aşamasına katkıda bulunmuştur.

\section{Veri kullanılabilirliği}

$\mathrm{Bu}$ çalışmanın bulgularını destekleyen veriler makul talep üzerine sorumlu yazardan temin edilebilir.

\section{Teşekkür}

$\mathrm{Bu}$ araştırma Burdur Mehmet Akif Ersoy Üniversitesi Bilimsel Araştırma Projeleri Koordinatörlüğü tarafindan 0577-YL-19 proje numarası ile desteklenmiştir.

\section{KAYNAKLAR}

1. Berger A, Willi B, Meli ML, Boretti FS, Hartnack S, Dreyfus A et al. Feline Calicivirus and other respiratory pathogens in cats with Feline Calicivirus related symptoms and in clinically healthy cats in Switzerland. Vet Res 2015;11:1-12.

2- Radford AD, Addie D, Belák S, Boucraut-Baralon C, Egberink H, Frymus $\mathrm{T}$ et al. Feline Calicivirus infection. ABCD guidelines on prevention and management. J Feline Med Surg 2009;11(7):556-64.

3- Coyne KP, Jones BRD, Kipar A, Chantrey J, Porter CJ, Barber PJ et al. Lethal outbreak of a disease associated with feline Calicivirus infection in cats. Vet Record, 2006a;158:544 550 .

4- Reynolds BS, Poulet H, Pingret JL, Jas D, Brunet S, Lemeter $\mathrm{C}$ et al. A nosocomial outbreak of feline Calicivirus associated virulent systemic disease in France. J Feline Med Surg 2009;11(8):633-644.

5- Dowers KL, Hawley JR, Brewer MM, Morris AK, Radecki SV, Lappin MR. Association of Bartonella species, feline Calicivirus, and feline herpesvirus 1 infection with gingivostomatitis in cats. J Feline Med Surg, 2010;12(4):314321.

6- Coyne KP, Dawson S, Radford AD, Cripps PJ, Porter CJ, McCracken $\mathrm{CM}$ et al. Long term analysis of feline Calicivirus prevalence and viral shedding patterns in naturally infected colonies of domestic cats. Vet Microbiol 2006b;118(1-2):12 25 .

7- Coyne KP, Gaskell RM, Dawson S, Porter CJ, Radford AD. Evolutionary mechanisms of persistence and diversification of a Calicivirus within endemically infected natural host populations. J Virology, 2007;81(4):1961-1971.

8- Foley J, Hurley K, Pesavento PA, Poland A, Pedersen NC. Virulent systemic feline Calicivirus infection: local cytokine modulation and contribution of viral mutants. J Feline Med Surg 2006;8:55-61.

9- Poulet H, Jas D, Lemeter C, Coupier C, Brunet S. Efficacy of a bivalent inactivated non-adjuvanted feline calicivirus vaccine: Relation between in vitro cross-neutralization and heterologous protection in vivo. Vaccine 2008;26:3647-3654.

10- Antonioli L, Colucci R, La Motta C, Tuccori M, Awwad O, Da Settimo F, Blandizzi C, Fornai M. Adenosine deaminase in the modulation of immüne system and its potential as a novel target for treatment of inflammatory disorders. Current Drug Targets, 2012;13:842-862.

11- Brigida I, Sauer A, Ferrua F, Gianelli S, Scaramuzza $\mathrm{S}$, Pistoia $\mathrm{V}$ et al. B-cell development and functions and therapeutic options in adenosine deaminase-deficient patients. J. Allergy and Clin Immunol, 2014;133:799-806.

12- Climent N, Martinez-Navio JM, Gil C, Garcia F, Rovia C, Hurtado C et al. Adenosine deaminase enhances T-cell response elicited by dendritic cells loaded with inactivated HIV. Immunol and Cell Biology 2009; 87:634-639.

13- Flinn AM, Gennery A. Adenosine deaminase deficiency: a review. Orphanet J Rare Dis 2018;13:1-7.

14- Ceron JJ, Tecles F, Tvarijonaviciute A. Serum paraoxonase 1 (PON1) measurement: an update. BMC Vet Res 2014;10:1-11.

15- Kulka M. A review of paraoxonase 1 properties and diagnostic applications. Polish J Vet Sci 2016;19:225-232.

16- Litvinov D, Mahini H, Garelnabi M. Antioxidant and Anti-Inflammatory Role of Paraoxonase 1: Implication in Arteriosclerosis Diseases. North Am J Med\&Sci 2012;4(11):523-532.

17- Meazzi S, Ferriani R, Paltrinieri S, Giordano A Preliminary data about Paraoxonase-1 (PON-1) as a maker for Feline Infectious Peritonitis (FIP). Int J Health, Anim Sci \& Food Safety, 2018;5(1):1-5.

18- Shunmoogam N, Naidoo P, Chilton R. Paraoxonase (PON)-1: a brief overview on genetics, structure, polymorphisms and clinical relevance. Vascular Health and Risk Management, 2018;14:137-143.

19- Chiu IM, Huang LC, Chen IL, Tang KS, Huang YH. Diagnostic values of $\mathrm{C}$-reactive protein and complete blood cell to identify invasive bacterial infection in young febrile infants. Pediatrics and Neonatology 2019;60:197-200. 
20- Gökce Hİ ve Bozukluhan K. Çiftlik Hayvanlarında Önemli Akut Faz Proteinleri ve Bunların Veteriner Hekimlikte Alanındaki kullanımı. Dicle Üniv Vet Fak Derg 2009;1(1):1-14.

21- Sproston NR, Ashworth JJ. Role of C-Reactive Protein at Sites of inflammation and infection. Frontiers in Immunology, 2018;9:1-11.

22- Schulz C, Hartmann K, Mueller RS, Helps C, Schulz BS. Sampling sites for detection of feline herpesvirus-1, feline Calicivirus and Chlamydia felis in cats with feline upper respiratory tract disease, J Feline Med Surg 2015;17(12):10129.

23- Akhtardanesh B, Ghalekhani, N, Abshenas J, Nematollahi H, Sharifi H. Serum adenosine deaminase as a diagnostic marker of chronic infectious disease in dogs. Vet Res 2013;17:592-595.

24- Baba K, Hoosen AA, Langeland N, Dyrhol-Riise AM. Adenosine Deaminase Activity Is a Sensitive Marker for the Diagnosis of Tuberculous Pleuritis in Patients with Very Low CD4 Counts. PLOSone, 208;3:1-5.

25- Ellah MRABD, Nishimori K, Goryo M, Okada K, Yasuda J. Serum adenosine deaminase activity in bovine liver diseases, J Vet Med Sci, 2004;66(11):1421-1422.

26- Kahraman MA, Gökce HI. Investigations of Adenosine Deaminase and C-reactive Protein in Cats with Feline Infectious Peritonitis. MAE J Health Sci Inst., 2020; 8,98-107.

27- Rodrigues DSLF, Oliveira, MEF, Teixeira PPM, Cavalcante IJM, Vale MR). Adenosine deaminase activity as a biochemical marker of inflammatory response in goats infected by caprine arthritis-encephalitis virus. Small Rum Res 2012;108(1-3):120-126.

28- Çırak KA, Tekgül S, Bilaçeroğlu S, Kömürcü B, Uçar MA, Yalnız E. Diagnostic values of pleural fluid, and serum C-reactive protein, Adenosine deaminase, and Lactate dehydrogenase levels and pleural fluid/serum ratios in the differentiation of malignant from benign pleural effusions. İzmir Göğüs Hastanesi Dergisi, 2012;2:75-82.

29- Kim JW, Yang IA, Oh AE, Rhyhoo YG, Jang YH . C reactive protein, sialic acid and adenosine deaminase levels in serum and pleural fluid from patients with pleural effusion. The Korean J Int Med 1988;3:122-127.

30- Novak F, Vavrova L, Kodydkova J, Novak F Sr, Hynkova M, Zak A et al. Decreased paraoxonase activity in critically ill patients with sepsis. Clin Exp Med 2010;10:21-25.

31- Scavone D, Sgorbini M, Borges AS, Oliveira-Filho JP, Vitale V, Paltrinieri S. Serial measurements of Paraoxonase-1 (PON-1) activity in horses with experimentally induced endotoxemia. BMC Vet Res 2020;16:1-7.

32- Farid AS, Kazuyuki Honkawa K, Fath EM, Nonaka N, Horii Y. Serum paraoxonase-1 as biomarker for improved diagnosis of fatty liver in dairy cows. BMC Vet Res, 2013;9:111.
33- Rossi G, Giordano A, Pezzia F, Kjelgaard-Hansen M, Paltrin S. Serum paraoxonase 1 activity in dogs: Preanalytical and analytical factors and correlation with $\mathrm{C}$-reactive protein and alpha-2-globulin. Vet Clin Pathol, 2013;42:329-341.

34- Ruiz-Gonzalez A, Bielsa S, Falguera M, Porcel JM. The Diagnostic Value of Serum C-Reactive Protein for Identifying Pneumonia in Hospitalized Patients with Acute Respiratory Symptoms. J Biomarkers, 2016;2016:1-5.

35- Kodama J, Miyagi Y, Seki N, Tokumo K, Yoshinouchi M, Kobashi $Y$ et al. Serum C-reactive protein as a prognostic factor in patients with epithelial ovarian cancer. European Journal of . Obstetrics\&Gynecology 1999;82:107. 